\title{
Depiction of Human Tragedy in Literary Works
}

\author{
Ochilova Nilufar O'Imasovna, Toirova Umida Sobirovna
}

\begin{abstract}
Nickolas Nickleby is a romantic novel written by Charles Dickens, one of the prominent English writer of Elizabethan era remembered as the greatest novelist with his literary contributions in the form of novels, short stories, poetry and plays. Famous works among his numerous writings include "A Message from the Sea", "Great Expectations", "Oliver Twist", and "A Tale of Two Cities". Nicholas Nickleby is one of examples of the romantic genre in Charles Dickens works and it is his third novel. This novel explores the life and adventures of a young man named Nicholas Nickleby, who has to support his mother and sister, due to unexpected failure of his father. Nicholas Nickleby's father loses his entire life savings and this results in his death. The family leaves from the comfortable life style and reaches their relative for support. The work shows real human tragedy which is analysed in this article.
\end{abstract}

Keywords : Human tragedy, sense of moral values, sentiment, ego identity, ego diffusion.

\section{INTRODUCTION}

$\mathrm{N}_{\text {ickolas Nickel by is a romantic fiction }}$ novel written by Charles Dickens, an English writer of Victorian era remembered as the greatest novelist with his literary contributions in the form of novels, short stories, poetry and plays. Notable works among his numerous writings include A Message from the Sea, Great expectations, Oliver Twist, and A Tale of Two Cities.

\section{LITERATURE REVIEW}

Nicholas Nickelby initiated the romantic genre in Charles Dickens works and it is his third novel. This novel explores the life and adventures of a young man named Nicholas Nickleby, who has to support his mother and sister, due to unexpected demise of his father. Nicholas Nickleby father loses his entire life savings and assets in a poor investment, resulting in his death. The family leaves from the comfortable life style and reaches their relative for support.

Revised Manuscript Received on October 15, 2019.

* Correspondence Author

Ochilova Nilufar O'Imasovna*, A teacher of Foreign languages faculty, Bukhara State University, Uzbekistan

Toirova Umida Sobirovna, A teacher of Foreign languages faculty, Bukhara State University, Uzbekistan

\section{METHODS AND METHODOLOGY}

Nicholas Nickelby is, as we have seen, a moral fable which well expresses young Dickens' sense of moral values. It forms a world, where the young novelist draws a sharp distinction between good characters and bad ones by the' purity of their "hearts," and where the good-hearted emerge triumphant, while the corrupt-hearted are defeated. This sentiment of Dickens' certainly strikes the sophisticated reader as a naive assumption which it is. Maybe Dickens knew it. After going through many hardships in the heartless world, where (it seemed at least to Dickens that) many people are only pursuing their own self-interests at the expense of the socially underprivileged, he was irresistibly driven to portray in this novel the world as he wished it were. In this sense Nicholas Nickelby is an instance of young Dickens' wish-fulfillment and his escape from reality.

\section{DISCUSSION}

Far from presenting a kind of escapist romp, he was offering his readers a vehicle through which he could express the world-view earlier expressed in his essay on "The Pantomime of Life" in Bentley's Miscellany that "the close resemblance which the clowns of the stage bear to those of every-day life is perfectly extraordinary" the implication being that society itself is a pantomime, in which people act outrageously and risibly. This invites the Bahktinian corollary that the carnavelesque has a subversive purpose, providing a diversity of voices and provoking a diversity of responses, producing fluidity, liberation and change - providing, in fact, "an opportunity for changing his readers' basic stories about the nature of reality" . Bahktinian readings, bringing out the fantastical in the text, and showing the subversive purposes it serves, seem highly appropriate here. After all, this was the novel that had the most direct and specific impact of all Dickens's novels, making the so-called "Yorkshire schools" notorious, and forcing their closure. 
As in Oliver Twist, which he was finishing while writing the earlier chapters, the general idea was to show goodness endangered but finally triumphant.

Amazed by what he sees at the school, and laid siege to by the simpering Fanny Squeers, Nicholas is now exactly at the stage Rousseau sketches further on in Émile: "he knows what is done in society; it remains for him to see how one lives in it" (327). According to Rousseau, this period, when the youth is first let loose in the adult world, is one of "so great and so sudden a change" that it is truly a dangerous time for him, when he is liable to become both vulnerable and "jaunty" (330). As for the former, we learn in the opening chapter that Nicholas has been brought up by a good, if weak and hen-pecked, father who values "the quiet routine of a country life" much like the one Rousseau proposes for his Émile. In this respect, the youth has been as properly preserved from the "great world" and its vices as Rousseau would have wished. Consequently, he is not influenced by his new companions, or drawn to their way of thinking. As to the latter, he becomes jaunty, as he strikes a pose with Squeers, flourishing words and blows together when he leaps to Smike's defence. Far from swaggering or trying to look good in order to impress, however, he is launching himself boldly and effectively against corruption and cruelty; the "inflated stage diction" here, as elsewhere, expresses what he truly feels in his heart. This first encounter is an important milestone for him. He, who had previously thought he should follow the path his uncle had laid out for him, is now following no one's principles but his own. And in doing so, he is choosing his path for himself, and taking his preliminary steps towards establishing his own identity.

Rousseau does not posit, let alone explore, adolescent angst during the critical period of choice, and nor does Dickens. It is enough for Rousseau that the youth should now manage to "cut out his own road to happiness following in no one else's tracks" (223), and for Dickens that his hero should make the right decision when confronted by difficult circumstances. Nevertheless, there are many hints of the novelist's interest in the developing self. Indeed, much that Nicholas does can be interpreted in light of later ideas about it. In particular, from this point, "the very process of growth provides new energy even as society offers new and specific opportunities" for its use. Having successfully stood up to the preposterous Squeers, Nicholas is now able to deal with the far more insidiously evil Ralph Nickleby. Realising that his uncle has no one's best interest at heart except his own, in successive episodes he refuses to tolerate what should not be tolerated - his uncle's

cold-heartedness towards his bereaved mother and disrespect to his sister, and, later on, the cruel sacrifice of his beloved Madeline to Gride. On this last occasion, he manages to keep his composure, presses his sister's arm reassuringly, and stands "erect and undaunted, front to front with his unworthy relative", ready to take any action required to thwart the mismatch. He seems, now, every inch a man. But all these encounters represent very important advances, both for Nicholas and his author. For here is a romantic hero who demonstrates that vigour is no longer all on the side of evil. A character has now appeared who, though he is impetuous, is willing to take the initiative and shape his own future. It is worth remembering at this point that many of Dickens's first readers considered Nicholas to be sufficiently natural, so much so, that Dickens felt the need to defend him against those who found him too natural - that is, too hot-blooded: "young men are rash, very rash," comments Mr. Crummles later (398). But the important point is that Nicholas's rashness at Dotheboys Hall, and afterwards, is all on the side of good.; this is what makes him a worthy hero.

\section{ANALYSIS}

The Significantly, John Carey talks of Nicholas's "impressive showing" (29) in this first episode. It needed to be a "showing" or indeed a show, and a convincing one, because after all he is just a slip of a lad in himself. We are told that to John Brodie he must have "seemed a mere dwarf". The hulking Yorkshireman is perfectly amazed by his feat: "Beatten the schoolmaster! Ho! ho! ho! Beatten the schoolmaster!" he cries, startling his horse when he meets Nicholas on the footpath afterwards. "God, it's the best thing a've heerd this twenty year!".

Smike is important for eliciting Nicholas's first strong performance, and the reader's sympathy, and also for showing Dickens's insight into the psychological springs of human behaviour. Critics sometimes fail to recognize the particularity of his case, and see Smike as the repository of Nicholas's inner life: he "exaggerates and makes visible the inner wounds that Nicholas suppresses," claims Paul Davis. But the childhood experiences 
of each have been totally different. Nicholas, as he himself never forgets, is the "son of a country gentleman" (417); his widowed mother, though comically lacking in judgment and even common sense, has not lacked affection. Indeed, she "still doted on her children" (28). Smike's development, on the other hand, has been stunted by deprivation and cruelty, his "years of misery and suffering lightened by no ray of hope." Making his own psychological analysis here, Dickens describes a case

"The chords of the heart, which beat a quick response to the voice of gentleness and affection, must have rusted and broken in their secret places, and bear the lingering echo of no old word of love or kindness" (Chapter 20, 500).

The physical illness that carries Smike off is so accurately described that Dickens's account of it could be cited in contemporary medical books; but this explanation of Smike's mental dullness is even more commendable. It reveals an understanding of the consequences of prolonged emotional neglect that was entirely lacking in Oliver Twist. Smike is so damaged that, unlike his cousin, he can never grow up to man's estate.

In recent thinking, the opposite outcomes of adolescence are seen as the achievement of a stable sense of self (Erikson's "ego identity"), and the failure to commit to a course in life (Erikson's "ego diffusion"). Nicholas attains the former: Dickens shows him deliberating over his future, withdrawing from his family "Seriously to reflect upon the state of his affairs, and to determine, if he could, upon some course of life which would enable him to support those who were so entirely dependent upon his exertions" Nicholas Nickleby. this is when he firmly decides against an acting career, on the sensible grounds that he may not, after all, be the right material for it, and that it would be an inconvenient way of life for his mother and sister. When, immediately after this, he meets one of the Cheeryble brothers, he appreciates their good-heartedness and quickly settles down to work in their counting-house with "steadiness and perseverance". This is largely in line with the idea that "the identity-achievement subject" has "seriously considered several occupational alternatives and has made a decision on his own terms," achieving "a resolution that leaves him free to act". Smike's case, however, is not the opposite. He lies nowhere on the scale of playboy to schizoid on which the "identity-diffusion subject" can be placed.

Rather, his is a case of "foreclosure," that is to say, of accepting, without the kind of healthy deliberation in which Nicholas engages, a course laid out for him by others. The "poor, unoffending, injured lad" has simply attached himself to Nicholas with dog-like devotion, exhibiting exactly the tendencies towards obedience, submission, shaky self-esteem, and vulnerability to stress, found in such subjects. Dickens's insight here is remarkable, confirming Freud's opinion that, while the social scientist will consciously observe processes "so as to be able to elicit and announce their laws," writers have always attended to them unconsciously, understanding their "possible developments and artistic expression".

Smike himself is well aware of his limitations, and becomes doubly so when he has to learn few lines for Romeo and Juliet. Dickens's choice of this part for him is apt. Romeo comments thus on evident poverty: "The world is not thy friend nor the world's law:/The world affords on law to make the rich" Smike is beyond the pale, his chances of improvement non-existent. "I want no clothes," he tells Nicholas early on, "drawing his rags together".

John Forster claims that as many people begged Dickens not to kill Smike, as women of an earlier generation had petitioned Richardson on behalf of Clarissa. But by this point he has come to be of secondary interest. The romances of the two Nickleby children have blossomed, and he has fallen into the background, literally retiring into his own room when young Frank Cheeryble comes to court Kate. His role now is as part of the plot machinery that will bring Ralph Nickleby to book. For his suffering is finally to be laid at the door, not only of Squeers and his cruel regime in Yorkshire, but of the father in whom greed for money had eclipsed all natural feeling.

It seems fair that, in the last words of the novel, Smike should be referred to as the "dead cousin" of the new generation of Nicklebys, rather than of Nicholas himself. "Foreclosure" seems the right word for his life on every score.

Earlier in the narrative, Dickens had consciously separated his bold, gallant hero from all taint of the grave with which Nicholas had originally comforted Smike by promising to share the same doom:

"'I tell you,' said Nicholas, 'that the same fate shall be ours in life and the same grave shall hold us both in death."

Dickens was right to have cut these words; they are not consonant with the

"sanguine temperament"

that Nicholas feels lucky 
to possess. In the event, the young hero nurses his dying cousin tenderly among the scenes of his own happy youth, to which the whole Nickleby family returns in the end. Nicholas has continued to thrive, has become, in fact, "a rich and prosperous merchant", and has bought back the old family home. The mood at the end is nostalgic, but not as nostalgic as it might have been. With Kate and her family living nearby as well, there are too many new young faces for such as that. In conclusion, it is obvious that the book shows the real social life full of sorrows, egoism and melancholic people. Illiteracy lead people to death and living in poor conditions. From the beginning of the book, the reader faces with the death of two people.

\section{CONCLUSION}

It can be concluded, Charles Dickens was one of the prominent writers of the XIXth century who demonstrated real life situations in England. The writer reveals challenging life, attitude of people to the society and how people had tragic life in their lifespan. Inner thoughts, self-realization, ego analysis, psychological effects of the environment are of the importance to be analysed in Dicken's work "Nickolas Nickelby". Having thoroughly analysed the characters, setting, psychological surrounding we came into following conclusion:

A. Charles Dickens as a realist writer depicts sorrows and happiness of the people, situations happened at that time;

B. His writing style differs from other writers with its colorfulness, richness in stylistic devices and character description;

C. Nickolas Nickelby is one of the mostly read and criticized books of Charles Dickens and shows real life of the characters;

D. The main human tragedy in the book is the poverty which blocks the ways of literate people to find their way in life; another one is the egoism of people who always try to be on the top in the society. In recent thinking, the opposite outcomes of adolescence are seen as the achievement of a stable sense of self (Erikson's "ego identity"), and the failure to commit to a course in life (Erikson's "ego diffusion").;

E. Gender difference is clearly stated human tragedy in the book with the examples of women who are not allowed to work;

F. Depiction of human tragedy is represented by different ways as clothes, attitudes, death of the two young characters;

G. This is fundamentally a hopeful work that has struck many critics showing Dickens in his "boyish mood" ;

H. It also features a large number of characters who are children in age as well as behaviour.;

I. Nicholas has taken a very active part in his own success. Nicholas Nickleby, as earlier criticisms of it would suggest, is not really susceptible to detailed character-analysis of the traditional type, and is not seen at its best when subjected to it;

J. As ideas about the self became more sophisticated in the Victorian age as a whole Kincaid, Dickens would grow more adept at unfolding his characters' inner lives. But his acuity even in his early novels should not be underestimated. This one is by no means a stage strutted by stock figures. It shows a great interest in childhood and how children develop. It draws just as much on the literary tradition of the bildungsromans on the conventions of the theatre, and not just in an old-fashioned way.

K. Nicholas Nickelby is, as we have seen, a moral fable which well expresses young Dickens' sense of moral values. It forms a bipolar world, where the young novelist draws a sharp distinction between good characters and bad ones by the' purity of their "hearts," and where the good-hearted emerge triumphant, while the corrupt-hearted are defeated. This sentiment of Dickens' certainly strikes the sophisticated reader as a naive assumption which it is. Maybe Dickens knew it. After going through many hardships in the heartless world, where (it seemed at least to Dickens that) many people are only pursuing their own self-interests at the expense of the socially underprivileged, he was irresistibly driven to portray in this novel the world as he wished it were. In this sense Nicholas Nickelby is an instance of young Dickens' wish-fulfillment and his escape from reality.

L. Nickolas Nickleby is a romantic fiction novel written by Charles Dickens, an English writer of Victorian era remembered as the greatest novelist with his literary contributions in the form of novels, short stories, poetry and plays. Notable works among his numerous writings include A Message from the Sea, Great expectations, Oliver Twist, and A Tale of Two Cities.

M. Nicholas Nickleby initiated the romantic genre in Charles Dickens works and it is his third novel. This novel explores the life and adventures of a young man named Nicholas Nickleby, who has to support his mother and sister, due to unexpected demise of his father. Nicholas Nickleby father loses his entire life savings and assets in a poor investment, resulting in his death.

This novel also contains features of realism as the fiction is interwoven with historical facts and existing figures of the 19th century to whose turn the novel is situated. The anchorage into this particular time is just deliberate as Charles Dickens comments on the rise of feminist issues that took place in this particular historical period. As the development of interest to literature and language learning in Uzbekistan the youth and many scientists began to work on the works of world literature. 


\section{REFERENCES}

1. Ackroyd, Peter. Dickens: A Life. London: Sinclair Stevenson, 1990.

2. Bolton, Philip H. Dickens Dramatized. London: Mansell, 1987.

3. Carey, John. The Violent Effigy: A Study of Dickens' Imagination. 2nd ed. London: Faber, 1991.

4. Chesterton, G. K. Appreciations and Criticisms of the Works of Charles Dickens. New York: Haskell House, 1970.

5. Chittick, Kathryn. Dickens and the 1830s. Cambridge: Cambridge University Press, 2010.

6. Collins, Philip, ed. Dickens: The Critical Heritage. Routledge \& Kegan Paul, 1971.

7. Davis, Paul. The Penguin Dickens Companion: The Essential Reference to His Life and Work. London: Penguin, 1999.

8. Davis, Paul. The Penguin Dickens Companion: The Essential Reference to His Life and Work. London: Penguin, 1999.

9. Dickens, Charles. The Letters of Charles Dickens. Vol 1 (1820-39), ed. Madeline House and Graham Strorey. Oxford: Clarendon Press, 1965.

10. Eigner, Edwin. The Dickens Pantomime. Berkeley: University of California Press, 1989.

11. Erikson, Erik H. Identity: Youth and Crisis. New York: W. W. Norton, 1968.

12. Fawcett, F. Dubrez. Dickens the Dramatist: On Stage, Screen and Radio. London: W. H. Allen, 1952.

13. Forster, John. The Life of Charles Dickens. 2 vols. London: Dent, 1927. 